\title{
Pamiętniki o Janie Śniadeckim, jego życiu prywatnym i publicznym i dziełach jego (t. 1, Wilno 1865, s. 848-868)
}

Postrzegając Śniadecki wzrastającą dążność między niektórymi u nas pisarzami, a szczególnie w Warszawie, do przyswojenia filozofii Niemieckiej, mianowicie zaś świeżo wtenczas rozgłoszonej po kraju nauki Kanta, czemu dowodził przed innymi Szaniawski' ${ }^{1}$ zajął się napisaniem pierwszej swojej

${ }^{1}$ Józef Kalasanty Szaniawski (1764-1843) - filozof, tłumacz, polityk. Jeden z pierwszych popularyzatorów filozofii niemieckiej wśród Polaków. Początkowo działacz ruchu patriotycznego, uczestnik powstania kościuszkowskiego. Sekretarz Warszawskiego Towarzystwa Przyjaciół Nauk w latach 1802-1804 i jego aktywny członek. Od 1806 urzędnik struktur administracji zaborczej, najpierw pruskiej, a następnie rosyjskiej (znany cenzor od 1822). W 1830 wyemigrował do Wiednia, skąd wrócił po trzech latach, angażując się w prace Rady Wychowania i Rady Stanu. Opublikował m.in.: Co iest filozofja (Warszawa 1802); O znamienitszych systemach moralnych starożytności, „Roczniki Warszawskiego Towarzystwa Przyjaciół Nauk” 1803, t. 2 (oraz w tym samym roku wydane osobno); System Chrystianizmu krótko wyłożony, „Roczniki Warszawskiego Towarzystwa Przyjaciół Nauk” 1803, t. 2 (oraz w tym samym roku wydane osobno); Rzut oka na dzieje filozofji od czasu upadku jej u Greków i Rzymian, aż do epoki odrodzenia nauk, „Roczniki Warszawskiego Towarzystwa Przyjaciół Nauk” 1804, t. 3 (oraz w tym samym roku wydane osobno ze znamiennym dodatkiem pt. O sceptykach moralnych i o szkodliwem dażeniu filozofji XVIII wieku); Rady przyjacielskie młodemu czcicielowi nauk i filozofji, pragnącemu znaleźć pewniejszą drogę do prawdziwego i wyższego oświecenia, Warsza- 
rozprawy O filozofii ${ }^{2}$. A ponieważ i w Wilnie pomiędzy uczniami zaczęto rozumować o tej nauce i okazywać chęć zgłębiania jej tajemnic; z drugiej zaś strony między różnymi stanami i odcieniami publiczności rozprawiano o filozofii, uwalając ją zupełnie i najczęściej z fałszywego stanowiska, niekiedy nawet nie wiedząc czym się zajmuje i co jest właściwie jej przedmiotem; postanowił choć pobieżnie coś powiedzieć, dla sprostowania wyobrażeń o owej mało jeszcze znanej i uprawianej filozofii, (której katedry w Uniwersytecie [Wileńskim] tak pożądano ${ }^{3}$ ) między młodzieżą i publicznością. Ale dla Wil-

wa 1805 (drugie wydanie głównej rozprawy filozoficznej Szaniawskiego opublikowane zostało w 1823 roku, we Lwowie).

${ }^{2}$ O filozofii [rzecz czytana na sesji literackiej Uniwersytetu Wileńskiego dnia 27 kwietnia 1819 r.], „Dziennik Wileński”, t. 1, 1819, nr 6, s. 457-481.

${ }^{3}$ Baliński podkreśla, że po kasacie zakonu jezuitów (niezupełnej na terenach zaboru rosyjskiego), w roku 1781 dawny uniwersytet został decyzją Komisji Edukacji Narodowej przekształcony w Szkołę Główną Litewską, w której nie wykładano w ogóle filozofii, stosując się do zarządzeń Komisji. Ten wątek podnosi, jako jeden z walorów ówczesnej uczelni Śniadecki w Żywocie literackim Hugona Kołłątaja (a potem w eseju O metafizyce) „... dzięki radom Kołłątaja, a mądrości Komisyi edukacyjnej, ta ostatnia nie dopuściła do krajowych Akademii metafizyki, nauki w pewnem znaczeniu ważnej dla małej bardzo liczby głów już gruntownie uczonych i obdarzonych siłą rozleglejszego rzeczy ogarnienia, ale najniebezpieczniejszej dla kraju, zaczynającego się porządnie uczyć. Uniknęliśmy przecież tej morowej na język i oświecenie zarazy, którą zostały dotknięte i podane na pośmiewisko prawdziwie uczonych Europy narodów Niemcy północne. Wskrzesiwszy dawne greckie i średniego wieku dziwactwa idealistów, dogmatyków i sceptyków i niemi jak opętani szperając w działaniach i władzach umysłowych, cedząc, dzieląc bez końca, anatomizując urojenia, tym nadając wyrazy, uprzędli transcendentalne nic, jako statut do sądzenia wiadomości ludzkich. Tę to fabrykę marzeń i czczych nazwisk [...] nazwali filozofią [...]. Należy to do chwały Kołłątaja, że on obronił od tego nieszczęścia nauki krajowe i język" (Pisma rozmaite, t. 1, s. 115). Wprawdzie w strukturach Szkoły Głównej nie było katedry filozofii, jednak wykłady z filozofii odbywały się nadal. Logikę wykładał Szymon Malewski (1793-1798), Mateusz Karaffa Korbutt (1798-1803) i Johann Heinrich Abicht (1804-1816). W okresie rektoratu Jana Śniadeckiego, Abicht pozostawał w otwartej opozycji wobec Śniadeckiego, aktywnie uczestnicząc w sporach po stronie frakcji profesorów cudzoziemskich. Wakat po śmierci Abichta utrzymywał się dość długo z powodu trudności w pozyskaniu odpowiedniego profesora (w tym czasie wykładał Maciej Staniewicz, który jednak czynił to zastępczo i w sposób niezadowalający; stanowisko to opuścił na własną prośbę w roku 1818). Pierwszym profesorem na nowo powołanej katedrze filozofii był - podobnie jak wcześniej Abicht, pozostający pod silnym wpływem filozofii Kanta - Anioł Dowgird (1818-1822), który jednak pełnił tę funkcję tylko tymczasowo. Nie uzyskał wtedy katedry filozofii, ponieważ w roku 1821, w wyniku konkursu, funkcję tę powierzono Józefowi Gołuchowskiemu (objął ją formalnie dopiero w roku 1822). Anioł Dowgird objął tę funkcję po Gołuchowskim i pełnił ją do czasu likwidacji uczelni w roku 1831. „Za czasów Uniwersytetu wykładano filozofię Kanta, Schellinga i wreszcie modyfikację kantowską wprowadził do 
na jeszcze nie oswojonego wówczas z tą nauką, należało inaczej mówić, jakby wypadało gdzie indziej. Już nieco dawniej w rozprawie swej $O$ metafizyce drukowanej w tomie II Pism rozmaitych ${ }^{4}$, zaczepił był Śniadecki o mistycyzm filozofii niemieckiej, i napadł na naukę Kanta, ale to było napisane dla uczonych tylko i to urywkowo. Dopiero w nowej rozprawie O filozofii, czytanej na sesji literackiej Uniwersytetu 15/27 kwietnia 1819 roku, dawszy najprzód wyobrażenie co rozumiano w starożytności, i co należy rozumieć pod nazwiskiem filozofii, zastanowił uwagę słuchaczów nad tym, że ta nazwa poważna nie może służyć nowo ogłoszonemu systematowi Kanta pod imieniem filozofii transcedentalnej, której treścią główną jest zbadanie „pierwszych przyczyn rzeczy"5, i usiłowanie rozważania ich, a priori, czyli niezawiśle od doświadczeń. Śniadecki zaś wychodził z tej zasady, że „pierwszym prawidłem zdrowej filozofii jest: nie szukać tego, co jest pojęciu naszemu od przyrodzenia zakazane, i co musi być dla niego wieczną tajemnicą" ${ }^{\text {; }}$ w jakim przypadku znajdują się pierwsze przyczyny rzeczy. Narzekając jednak na mistycyzm Kanta, niezrozumiałość wyrazów jego i śmiałe przypuszczenia, nie miał zamiaru tym razem przynajmniej rozszerzać się nad obalaniem tej nauki; zbił jej tylko zasady kategorycznie, lecz krótko. Zdaje się zaś, że rozprawa Śniadeckiego miała na celu przekonanie czytelników o mylności zarzutów czynionych prawdziwej filozofii, jakoby była rodzicielką wszystkich nadużyć okropnych rewolucji francuskiej, a w końcu niczym innym, jak tylko niedowiarstwem. Śniadecki śmiało całą potęgą pióra i całym ciężarem powagi swojej zgromił tu równie statystów, jak teologów takich, co niedowiarstwa i bezbożności miano nadawali filozofii. Otworzył on tą swoją rozprawą oczy, zarówno fanatykom, jak niedowiarkom ówczesnym, mianowicie miejscowym, jakie mają znaczenie przywiązywać do wyrazu 'filozofia', kończąc tymi pięknymi słowy rozprawę. „Religia jako dzieło boskie, obeszłaby się bez wszelkiej ludzkiej pomocy, ale jako sprawowana przez ludzi, przeciwko ich przewrotności potrzebuje usługi filozofii. Filozofia jest to użycie rozumu w poznawaniu świata. Jak religia, tak rozum są darami nieba, więc się łączyć razem i wspierać powinny do utrzymania porządku towarzyskiego, do skazania człowiekowi dróg szczęśliwości teraźniejszej i przyszłej, i do godnego uwielbienia Boga w roz-

wykładów Dowgird, który był ostatnim profesorem filozofii w Wilnie." J. Bieliński, Uniwersytet Wileński (1579-1831), t. 2, Kraków 1899-1900, s. 392.

${ }^{4}$ J. Śniadecki, Pisma rozmaite, t. 2, Wilno 1814, s. 333-358.

${ }^{5}$ J. Śniadecki, O filozofii, [w:] tenże, Pisma filozoficzne, red. D. Petsch, t. 2, Warszawa 1958, s. 167.

${ }^{6}$ Tamże. 
wadze, podziwieniu, i w prawem użyciu cudów i dobrodziejstw rozlanych w stworzeniu świata." I ten właśnie stosunek religii z filozofią, drugie walne twierdzenie i prawidło Śniadeckiego, nie pozwoliło mu iść za zdaniem tych, którzy utrzymują, że filozofia zawsze wyłącza religię, i nawzajem religia filozofię, tak, że nigdy razem z sobą iść nie mogą. Będąc astronomem przywykł obejmować umysłem cały majestat Stwórcy i wierzyć w jego wszechmocność. Będąc biegłym w naukach wiedział, że Bóg pozwolił człowiekowi rozważać i w pewnym zakresie śledzić tajemnice świata. Dedit Deus mundum disputationibus hominum! $!^{8}$ Skoro się rozczytano w tej rozprawie filozofii ogłoszonej w „Dzienniku Wileńskim”, miesiąc maj roku $1819^{9}$, stronnicy Kanta i niemieckiej filozofii oburzeni do żywego zuchwałością takiego buntu literackiego, zaczęli podnosić w niebo głosy przeciw Śniadeckiemu, że się nie w swoją rzecz wdał, że nawet nie czytał Kanta i nie umie po niemiecku itp. ${ }^{10}$. Umiarkowańsi mniemali, że Śniadecki nie jako znawca filozofii, lecz jako amator, jako wreszcie sam tylko matematyk, chciał wyrokować o nauce, którą tylko znał powierzchownie. Nie zastanowili się nieboracy, że właśnie matematyk głęboki, przywykły do rozumowania i subtelnych kombinacji, najprędzej był usposobiony do zgłębiania i rozwiązywania trudności zadań filozoficznych. Alboż Descartes, Newton, Leibniz i d'Alambert, nie byli razem filozofami i matematykami? ${ }^{11}$ Znalazł się wszakże jeden u nas ze zwolenników filozo-

7 Tamże, s. 185.

${ }^{8}$ Łac. Bóg pozwolił ludziom rozprawiać o świecie.

9 „Dziennik Wileński”, t. 1, 1819, nr 6, s. 457-481. Esej opublikowany został w numerze czerwcowym.

${ }^{10}$ Bieliński miesza dwie polemiki. Pierwszą dotyczącą pisma O metafizyce i drugą, wywołaną pismem O filozofii. Daty wskazują tu na tę drugą, ale sposób jej opisu dostarczony przez Bielińskiego bardziej pasuje do przebiegu ostrej krytyki wcześniejszej rozprawy zatytułowanej $\mathrm{O}$ metafizyce, której pierwsza anonimowa, niemieckojęzyczna recenzja, zawierająca wspomniane zarzuty, ukazała się w „Allgemeine Literatur-Zeitung” (1815 (Juli), nr 162, szpalta 513-518), a następnie wydana została w języku polskim z obszernym komentarzem jej anonimowego tłumacza („Pamiętnik Warszawski”, t. 3, 1815, nr 10, s. 236-259 (podpisano: „B. K. J.”)) i wywołała polemikę na łamach „Pamiętnika Warszawskiego”.

${ }^{11}$ Śniadecki wymienia wielokrotnie (chociaż w różnej konfiguracji) nazwiska cenionych przez siebie filozofów, będących jednocześnie przedstawicielami nauk ścisłych: Kopernika, Galileusza, Keplera i Newtona (O metafizyce, [w:] tenże, Pisma filozoficzne, t. 2, s. 159); Descartesa, Newtona i Leibniza (Przydatek do pisma O filozofii, tamże, s. 224 i nast.); Bacona, Pascala, Locke’a i d’Alemberta (tamże, s. 229). Nazwisko Kanta, na ogół zestawiane jest przez niego z Platonem (Przydatek do pisma O filozofii, s. 191, 194, 198, 216-217, 229), albo ze scholastyką (tamże, s. 192-193, 194, 229, 231-232, 234, 240) i zawsze w kontekście, który sugeruje przeciwstawne stanowisko wobec wymienionych filozofów-matematyków. 
fa królewieckiego, istotnie znający się na rzeczy, który się domyślił lepiej od innych z kim będzie miał do czynienia, wystąpił niebawnie, bo w październiku tegoż roku, w „Pamiętniku Lwowskim”, ze szczegółową, ale przyzwoitą recenzją, zbijając usilnie zarzuty Śniadeckiego przeciw Kantowi ${ }^{12}$. Miały one mniej więcej swoją wagę, jak się naturalnie dzieje $\mathrm{z}$ dowodami za i przeciw w hipotezach. Ale recenzent, nie bacząc, że spór zaczął z gruntownym i wyższego rzędu matematykiem, nieostrożnie zaczepił go w tej materii i naraził siebie na szwank pod tym względem.

Śniadecki znalazłszy w ogłoszonej krytyce jego pisma o filozofii w „Pamiętniku Lwowskim” trudności i zarzuty dość ważne, żeby dowieść, iż w sądzie swym o nauce Kanta nie był lekkomyślnym, zajął się napisaniem dość obszernej odpowiedzi na nie, którą pod tytułem: Przydatek do pisma O filozofii czytał najprzód na sesji literackiej [Cesarskiego] Uniwersytetu [Wileńskiego] 15 maja 1820 roku, a potem ogłosił drukiem w „Dzienniku Wileńskim” tegoż roku ${ }^{13}$. Tu już wszedłszy w szczegółowy rozbiór systematu Kanta i w porównanie go z odkryciami poprzedzających znakomitszych filozofów, okazał dowodnie jak dalece wdrożony był we wszystkie tajemnice filozofii, jak znał dokładnie naukę Kanta, (bo istotnie znał już ją od studiów swoich roku 1779-1781 w Getyndze) ${ }^{14}$, i jak wiedział dobrze czego chciał i czego bronił. Ta nowa rozprawa odsłoniła oczy w wielu względach lekkomyślnym wielbicielom szkoły niemieckiej, i wyprowadziła niektórych z błędu lekceważenia nauki Śniadeckiego. Nastąpiło więc przez lat kilka w tym sporze milczenie piśmienne, ale nie ustne, niedowarzeni filozofowie wtenczas i potem, a nawet do naszych czasów, powtarzali jak pacierz za panią matką, rozmaite pociski

12 Uwagi na pismem Jana Śniadeckiego: O filozofii. „Pamiętnik Lwowski”, 1819, nr 10, s. 296-309. Autorem recenzji, podpisanej pseudonimem Philopolski, był Tytus Dzieduszycki (1796$-1870)$.

${ }^{13}$ Przydatek do pisma o filozofii [rzecz czytana na sesji literackiej Wileńskiego Uniwersytetu dnia 15 maja 1820], „Dziennik Wileński”, t. 2, 1820, nr 2, s. 121-152, nr 3, s. 241-272.

${ }^{14}$ Teza ta nie może być prawdziwa. Nie ma żadnego potwierdzenia, że w tym czasie (a więc już w roku publikacji Krytyki czystego rozumu) Śniadecki zajmował się w jakikolwiek sposób filozofią Kanta. W rachubę wchodziłyby jedynie pisma przedkrytyczne. Jednak nawet i to jest mało prawdopodobne, jeśli uwzględnimy fakt, że w Getyndze w owym czasie przeważało zainteresowanie filozofią brytyjskiego empiryzmu. Jeden z czołowych filozofów getyngeńskiej uczelni, Johann Georg Heinrich Feder (1740-1821), za ostrą krytykę filozofii Kantowskiej już w rok później zapłacił utratą stanowiska. Jeśli więc jakakolwiek wiedza o filozofii Kanta w tym czasie dotarła do Śniadeckiego (choćby za pośrednictwem prac Federa), była raczej już polemiczna i zawierała jej krytykę. Por. S. Kaczmarek, Początki kantyzmu. Reakcja przeciw kantyzmowi w Polsce, Poznań 1961, s. 80-81. 
na Śniadeckiego, że murem chińskim chciał odgraniczyć młodzież polską od zagłębiania się w wyższe sfery ducha, że dlatego powstawał na filozofa królewieckiego, i tym podobne nonsensa, nie wiedząc $w$ istocie $w$ czym on zdrowo sądził o Kancie, a w czym nie mógł ostatecznie zwalić jego systematu.

Śniadecki będąc empirykiem, to jest opierającym się na doświadczeniu, a zatem sensualistą, to jest wyprowadzającym źródło wszelkich poznań ostatecznie ze zmysłów, wcale jednak nie został ani człowiekiem jedynie zmysłowym, czyli materialistą, ani sceptykiem, jak to poczytują filozofowie niemieccy za konieczność. Nie został zaś dlatego sceptykiem, że powiedziawszy raz: „Jak między fenomenami dat i pierwszą ich przyczyną, tak między światem zewnętrznym, a działaniem duszy, jest przepaść na której zgruntowanie nie masz w człowieku żadnej władzy i siły: i dla tego szperanie w tej przepaści prowadzi nie do myślenia, ale do zawrotu głowy"15 wyrzekł się właśnie dalszego zaciekania się i szukania pierwszej przyczyny fenomenów. Ale Kant puścił się w tę przepaść, i obdarzony wielką potęgą myślenia, wiele rzucił nowych pomysłów; długo wędrując jednak w tej nieznanej krainie myśli, zmuszony był tworzyć nowe wyrazy, które zaćmiły i utrudniły jego naukę, a na koniec równie jak jego poprzednicy, twórcy nowych systematów walących się jedne po drugich, i sam utknął na drodze teoretycznego rozumu, przyznając się do tego, że o najważniejszych przedmiotach dla człowieka nic wiedzieć nie może, i bytu ich ująć nie jest zdolnym. Nie mogąc jednak przestać na takim wypadku wynalazł drugi rodzaj rozumu, który nazwał praktycznym, i za pomocą którego wszystką już stronę duchową i moralną, człowieka mógł roztrząsać i celów jej dopytywać się. Lecz i tu Kant nie uniknął zarzutu przeciw jego systematowi, bo utworzywszy dwa rozumy, z których jeden teoretyczny ma tylko własność obserwacji, drugi praktyczny działa, nie dał im zgodnego między niemi stosunku, chociaż do jednej istoty należą. Nie nasza to rzecz, ani specjalność naukowa, wdawać się w tłumaczenie zasad i niedostatków następnych po Kancie filozofów szkoły niemieckiej. To tylko możemy powiedzieć, iż żaden nie zaspokoił zupełnie i do przekonania ciekawości i wątpliwości ludzkiej w rozwiązaniu przeznaczenia człowieka i dojścia do źródeł jego władz umysłowych. Większa część tych twórców systematów filozoficznych, dowiedli tylko, przez swój mistycyzm nie raz prawie niedający się pojąć, przez swoje zaciekania się w głębiach abstrakcji, potężnej siły w zapaśnictwie umysłowym, kończąc na tym, że nic, albo mało co więcej oświecili ludzi, nad to czego ich poprzednicy inną drogą nauczyli. Dla tych wszystkich przyczyn

${ }^{15}$ J. Śniadecki, O filozofii, s. 168. 
Śniadecki może być łatwo usprawiedliwionym, że bojąc się zostać z myśliciela marzycielem, a swoją powagą naukową dać otuchę młodzieży do bujania w krainie abstrakcji i odrywania jej od życia i zatrudnień praktycznych, wolał ją przez surową krytykę Kanta odstręczyć od badań oderwanych, a potem skierować na drogę łatwiejszej do pojęcia filozofii, w szkołach szkockich i angielskich przyjętej. Jeżeli przypuścimy, że zarzuty Śniadeckiego przeciw nauce Kanta nie wszystkie mogą się utrzymać i usprawiedliwić, przyznać mu jednak wypada, że on należy do najlogiczniejszych i najsilniejszych przeciwników jego. Kiedy Francuzom, Anglikom, i samym nawet Niemcom uczonym, można było zbijać tego filozofa, dlaczegóżby Śniadeckiemu nie godziło się należeć do jego przeciwników. Przeczytawszy z uwagą jego Przydatek do pisma O filozofii, trzeba uznać, że pojmował on dobrze czego chciał Kant, i że filozofia niemiecka od jej początku dokładnie mu była znajomą, a jako matematyk głęboki umiał i miał prawo spierać się o rozumowanie i wnioski matematyczne w nauce Kanta. Może Śniadecki zanadto żywych wyrazów użył w zbijaniu Kanta, może piórem tak zaostrzonym jak Hume’a kiedy gromił mistycyzm filozoficzny, objawiał swoją odrazę do transcendentalnej filozofii i twórcy jej, nie odmawiał mu przecie tytułu mędrca ${ }^{16}$. Wreszcie w każdym razie krytyka Śniadeckiego nie tylko nie była niewłaściwą, ale bardzo u nas pożyteczną, wyświecając wątpliwości w nowym systemacie i oswajając czytelników polskich z rozumowaniem w filozofii. Ileż ona sama od Greków przeszła zmiennych kolei, ileż jej najsłynniejszych upadło systematów? Zostałże i Kant niemylnym? Kiedy już i następca jego Hegel, niemniej potężny myśliciel, stracił urok, który go zrazu otaczał!

Tak tedy Śniadecki usiłując obalić naukę Kanta i młodzież polską od szkoły filozoficznej niemieckiej i jej zawiłych abstrakcji ochronić, musiał koniecznie, i za obowiązek sobie słusznie poczytał, coś takiego dla niej zbudować, gdzie by jej przyrodzona ciekawość i chęć nabywania coraz głębszej wiedzy świata duchowego, mogła znaleźć przytułek i zaspokojenie. Nie widząc zaś na to sposobu w szkole francuskiej przesadzającej w zaufaniu sile zmysłów, a następnie nurzającej się nieraz w materializmie, obrócił się do szkoły ówczesnej angielskiej czyli raczej szkockiej, idącej pośrednią drogą między zbytecznym poleganiem na zmysłach, a przesadzoną abstrakcją. Uznawał on, przypatrzywszy się dobrze usposobieniu naturalnemu swoich współziomków, że dla Polaków snadniej i pożyteczniej byłoby zająć się praktyczniejszą filozofią, unikając abstrakcji, do której Słowianie nie okazywali nigdy bardzo

${ }^{16}$ J. Śniadecki, Przydatek do pisma O filozofii, s. 242. 
wielkiego współczucia. „W kilku moich pismach - powiada Jan Śniadecki w przemowie do swego traktatu O filozofii umysłu ludzkiego - broniąc młódź polską przeciwko fałszywej filozofii, pomyślałem sobie, że nie dosyć jest ganić i zbijać jaką naukę; ale trzeba jeszcze pokazać młodzi krajowej, czego się ma w niej trzymać. To mię wciągnęło w czytanie i rozwagę znakomitszych dzieł zagranicznych o metafizyce i filozofii, jako o rzeczy, na której poznawaniu strawiłem znaczną część mojej młodości, nimem się całkiem do nauk matematycznych i fizycznych przywiązał. Pilna rozwaga dzisiejszej filozofii niemieckiej i francuskiej, wskazała mi egzageracją, czyli przesadę obydwóch: bo szkoła niemiecka przebrała miarę w zasadach Leibniza, szkoła zaś francuska przebrała ją w zasadach Locke'a. Wysilone szperania pierwszej, ubrane w niepojętą, a do niczego niesłużącą frazeologią, zrobiły z filozofii jakąś niezrozumianą tajemnicę, prowadzącą umysł ludzki do mistycyzmu, to jest do przywary i naukom szkodliwej, i prawdziwemu oświeceniu przeciwnej, i podającej nie tylko przytułek, ale nawet broń wszystkim naukowym oszustwom i kuglarstwom, które się w Niemczech pod opieką tej filozofii, tak swobodnie od jakiegoś czasu zaczęły rozpościerać i szerzyć. Zbytnie znowu uleganie w zmysłach szkoły francuskiej, otworzyło drogę do materializmu: który jest prawdziwym zabójstwem obyczajów, religii i porządku towarzyskiego. Tych dwóch ostateczności uniknęła szczęśliwie szkoła angielska. I naród ten, jak był pierwszym założycielem zdrowej filozofii w dziełach Bacona, Boyle'a, Newtona i Locke'a; tak dziś doskonaląc tę naukę, utrzymuje jej prawowierność i chwałę w pismach Hume’a, Reida, Dugalda Stewarta, Campbella, i innych." ${ }^{17}$ W lecie 1821 roku skończył Śniadecki pisać niewielkich wprawdzie rozmiarów, ale pełne treści dzieło, mające tytuł: Filozofia umysłu ludzkiego, czyli rozważny wykład sil i działań umysłowych, które w następnym 1822 roku wyszło na jaw wydrukowane w tomie czwartym Pism rozmaitych razem $\mathrm{z}$ dwiema już znanymi $\mathrm{z}$ „Dziennika Wileńskiego” rozprawami jego o filozofii. Przyjąwszy w nim układ szkoły angielskiej, a raczej szkockiej; mianowicie podług Reid’a i Dugald’a Stewarta, wziął za zasadę poznawać umysł ludzki przez śledzenie jego objawów, czyli przychodzić do poznania sił umysłowych z fenomenów już uznanych, nie zaś z domysłów. Wszakże nie idąc ślepo za przewodnikami, których sobie wybrał, starał się podopełniać to co mu się zdawało niedostatecznym, i własnym swoim sposobem wystawić naukę w niektórych rzeczach. A najprzód, usiłował odróżniać zdania potrzebujące dowodzenia, od fenomenów niepowinnych się dowodzić; po wtóre,

${ }^{17}$ J. Śniadecki, Filozofia umysłu ludzkiego, [w:] tenże, Pisma filozoficzne, t. 2, s. 248-249. 
nie wyprowadzać działań wyższych sił duszy z myśli pospolitych, ale z nauk i umiejętności, w których się właśnie pokazuje największa potęga sił umysłowych. Jak praktyczna dążność szkoły filozoficznej szkockiej, przy ciągłej usilności zwalczenia sceptycyzmu, a razem manifestowania przeciw metafizyce panującej w katedrach uniwersyteckich stałego lądu, miała na celu pomyślność kraju przez taki zwrot instrukcji publicznej; tak przyswojenie jej zasad w świecie naukowym polskim przez Śniadeckiego, skierowane było jedynie do ustrzeżenia młodzi krajowej od niewczesnych, a nieraz szkodliwych marzeń i zaciekania się w przesadzonej abstrakcji, z uszczerbkiem sił umysłu do życia praktycznego potrzebnych. Prawda, że to pismo jego zbyt krótko i treściwie wystawiało teorię jego systematu; ale zamierzył on tylko, jak sam powiada, wytknąć gościniec do śledzenia działalności umysłu ludzkiego, zostawiając resztę do myślenia czytającym, lub następnym po sobie pisarzom. Zakończył on swój traktat tym walnym zdaniem: „że filozofia nie będąc przysposobieniem, ani wstępem, lecz wypadkiem dobrze pojętych nauk"18, nie powinna, zaczynać, ale kończyć wyższą instrukcją szkolną! Cokolwiek bądź, zrobił ten znamienity pisarz większą przysługę w swoim czasie, jasnym swoim wykładem przystępnego systematu filozofii, niż owi wszyscy u nas tamtocześni popieracze szkoły niemieckiej. Wreszcie pożyteczniej było dla uczącej się w kraju młodzi zaczynać od początków łatwiejszych bo zrozumialszych, jak zaraz łamać sobie głowę nad zawiłościami spekulacji, i przez to się od nauki filozofii odstręczać. W każdym razie Śniadecki, jak i wszyscy inni pisarze, powinni być oceniani względnie czasu, w którym ogłaszali swoje dzieła, a nie mierzeni na dzisiejszą skalę.

Tymczasem jakież to rozmaite i z gruntu jedne drugim przeciwne sądy o nim, wywołały ostatnie jego pisma? Im gorliwsi byli jego wielbiciele, im wdzięczniejsi uczniowie, tym bezwzględniejsi przeciwnicy. A cóż mówić o oszczercach, na których nigdy i nigdzie, a może więcej u nas, znakomitym ludziom nie zbywa. Ci byli najzajadlejsi! Jednakże znaleźli się i tacy, którzy umiarkowanie i sprawiedliwość zachowali w czynionych mu zarzutach. Oprócz krytyki „Pamiętnika Lwowskiego”, zbijano w kilka lat później argumenty Jana Śniadeckiego przeciw Kantowi w „Haliczaninie” Chłędowskiego (t. II roku 1830 ${ }^{19}$. I to jest podobno najuczeńsza krytyka mniemań filozoficz-

\footnotetext{
18 „filozofia nie jest przysposobieniem ani wstępem, ale jest wypadkiem dobrze pojętych i ogarnionych wiadomości i nauk, na niej kończyć się powinna instrukcja ludzi, nie za od niej się zaczynać" (tamże, s. 418).

${ }^{19}$ Chodzi o obszerne opracowanie autorstwa Walentego Chłędowskiego (1797-1846), pisarza, znakomitego tłumacza literatury niemieckiej, krytyka literackiego, filozofa oraz wydawcę
} 
nych Jana Śniadeckiego; bo choć mu recenzent nie przyznaje, żeby był właściwym sędzią filozofii niemieckiej, chociaż utrzymuje, że przejęty żywiołami wyciągniętymi z nauki Locke’a, Leibniza, Berkeley’a, Hume’a, Reida i Dugalda Stewarta, wpadł w też same błędy, co i oni, co do istoty i możliwości poznania ludzkiego; chociaż na koniec zarzuca mu niektóre sprzeczności w jego własnych zasadach, ale nie ubliżając ani jego rozległej nauce, ani wielkim zasługom w kraju, opiera przecie swoje przeciw niemu dowody na pewnym gruncie i na znajomości rzeczy, o której pisze. Krytyka ta przeważa wszystkie inne sądy o filozofii Jana Śniadeckiego, wtenczas i później ogłoszone, a jedne ogólny tylko widok nauki zawierające, drugie polemiczne za i przeciw niemu, trzecie zaś, co gorsza! płoche i nacechowane zupełną nieznajomością rzeczy. Szkoda, że zgon Śniadeckiego uprzedził ogłoszenie tej rozprawy krytycznej w „Haliczaninie”, bo nas pozbawił wiadomości, jaka by jego była odpowiedź na to i usprawiedliwienie się? a razem odparcie tego, co w tej krytyce było stronnego i niesłusznego. Nie ma co tu wspominać o sądach w tej materii umieszczonych w „Kwartalniku” z roku $1836^{20}$, bo ten sam jest duch krytyki zupełnie negacyjnej, tylko może więcej uprzedzenia i goryczy! Tymczasem przeciwnie pijarowie warszawscy przedrukowali część jego rozpraw o filozofii, dla upowszechnienia ich w Warszawie ${ }^{21}$. Audytorowie zaś Uniwersytetu Krakowskiego, spełniając wolę zmarłego w kwiecie wieku towarzysza swego, Eustachego Szopowicza, syna profesora, młodzieńca cnotami i nauką celującego, wydali na nowo trzy rozprawy Jana Śniadeckiego, O metafizyce, O filozofii i Przydatek do pisma o filozofii ${ }^{22}$, nakładem uczniów tegoż uniwersytetu dla rozszerzenia pomiędzy nimi praktyczniejszych zasad filozofii i ustrzeżenia ich od zawiłych hipotez szkoły niemieckiej.

i redaktora („Pamiętnika Lwowskiego” oraz „Haliczanina”). W t. 2 „Haliczanina” ukazała się obszerna rozprawa poświęcona ówczesnej filozofii pt. O filozofii (cz. II, Obraz filozofii Niemców od Kanta aż do najnowszych czasów), s. 1-53. Chłędowski należy do największych propagatorów ówczesnej filozofii niemieckiej. Poza wymienionym tytułem, na uwagę zasługują nieopublikowane teksty: Listy do kumy oraz Krytyka listów estetycznych Kremera.

${ }^{20}$ Chodzi o „Kwartalnik Naukowy”, t. 3, Kraków 1836, z. 1, s. 10-50, gdzie opublikowany został tekst pt.: O zawodzie filozofii. Jako przyczynek do zawiąania się jej w kraju naszym (podpisany inicjałami „A. Z. H.”).

${ }^{21}$ Chodzi o Dzieła. Wydanie nowe Michała Balińskiego, t. 1-5, Warszawa 1837.

${ }^{22}$ Pisma Jana Śniadeckiego o filozofii Kanta, za staraniem T. E. Szopowicza, a nakładem uczniów Uniwersytetu Jagiellońskiego w Krakowie 1821, in 8vo, str. 114 i wspomnienia o Tad[euszu] Eus[tachym] Szopowiczu przez Ferdynanda Kojsiewicza str. XII, z wizerunkiem tegoż Szopowicza [przypis Balińskiego]. 
Żywsze zdania i natarczywsze napaści na pisma i zasady Śniadeckiego pojawiły się w dziesięć lat niemal od zgonu jego. Pewien znakomity pisarz ${ }^{23}$ dowcipem i rozległymi wiadomościami jaśniejący, lekceważącym piórem zaczął uwłaczać nauce i zasługom Jana Śniadeckiego, tym szkodliwiej dla prawdy i zdrowej krytyki, że zdanie jego aczkolwiek fałszywe, lecz wsparte powagą talentu, wpłynęło na młode głowy niezdolne jeszcze do utworzenia własnego sądu, i sformowało szereg bluźnierców przeciw sławie naukowej dobrze nabytej tego męża! Wkrótce jednak wystąpił inny pisarz także zdolny, ale większy miłością sprawiedliwości, który uważniej i szlachetniej go ocenił. Takim sprawiedliwie uznającym wyższość umysłową Jana Śniadeckiego i zasługę dla zbawiennej dążności pism jego, jest Tytus Szczeniowski ${ }^{24}$. W rozprawie swej O filozofii umieszczonej w „Athenaeum” roku 1841 tomie IV ${ }^{25}$, uważając Śniadeckiego jako potężnego przeciwnika nowej filozofii niemieckiej, nie ubliża zasłużonych pochwał jego zasadom, dzielności mowy i rozumowania. Nie można wprawdzie przyznać, że p[an] Szczeniowski w pobieżnej, ale rozważnej swojej krytyce, użył wszystkich dowodów za i przeciw metodzie filozoficznej Śniadeckiego, bo przecie o najważniejszej rzeczy zamilczał, to jest, że Śniadecki przyjął i pierwszy u nas wprowadził zasady szkoły filozoficznej szkockiej; wszakże p[an] Szczeniowski jest jednym z tej małej liczby krytyków naszych co do tego przedmiotu, który sądzi o Śniadeckim przeczytawszy pilnie jego pisma. Inni lubią wyrokować nie wiedząc nawet, co się w nich zawiera. W roku 1841 „Przegląd Warszawski” (Zeszyt III) wspomniał o empiryzmie Jana Śniadeckiego w filozofii, utrzymując ${ }^{26}$ : że oparłszy go na

${ }^{23}$ Trudno ustalić, czy chodzi o anonimowego tłumacza niemieckiej recenzji eseju O metafizyce (podpisującego się inicjałami „B. K. J.”) czy raczej o Tytusa Dzieduszyckiego, autora polemiki z pismem O filozofii. W rachubę wchodzą także - w kolejności chronologicznej wydanych publikacji - Maurycy Mochnacki, Michał Czacki i Walenty Chłędowski.

${ }^{24}$ Tytus Szczeniowski (1808-1880), pisarz, filozof, satyryk. Publikował na łamach wileńskiego „Athenaeum”, m.in. popularyzując filozofię Hegla: Parafrazy Hegla z jego wstępu do „Historii filozofii” (1842 t. 1, 2, 3), a także w broszurze: Przygotowania do nauki dziejów powszechnych $i$ historii rozwinięcia się umysłu $i$ ducha ludzkiego (Wilno 1842). W 1844, podczas pobytu w Warszawie zawarł znajomość z Eleonorą Ziemięcką.

${ }^{25}$ Rozprawa Szczanieckiego, pt. O filozofii, ukazała się w piśmie redagowanym przez J. I. Kraszewskiego, na s. 19-55, krytyka bezpośrednio odnosząca się do Jana Śniadeckiego rozpoczyna się na s. 36.

${ }^{26}$ Chodzi o niewielki tekst zatytułowany Jaki kierunek możnaby u nas nadać filozofii i jaki systemat rozwinąć, względnie do ducha narodu i położenia naszego współczeństwie (s. 273278; tekst podpisany: „M. Morz...”). Zdanie rozpoczyna się od otwartego cytatu, ale nim nie jest (być może dlatego interpunkcja jest niekonsekwentna). Baliński parafrazuje jedynie 
teoryi Locke’a, zatrzymał się na niej zastraszony zmysłową metafizyką Kanta, prowadzącą prosto do cynizmu i materializmu. Radził potem tenże „Przegląd [Warszawski]" odrzucając idealizm Hegla niestosowny dla Polaków, ale i nie idąc śladem matematycznym Śniadeckiego, szukać raczej w szkole eklektycznej właściwszej dla nas filozofii. Łatwo jest na to odpowiedzieć, że właśnie Śniadecki wpadł na tę myśl, tylko, że zamiast eklektyzmu z różnych systematów czerpanego, dał Polakom praktyczność szkoły szkockiej moderowaną własnymi pomysłami, w swoim traktacie O filozofii ${ }^{27}$. Na ówczesny zatem stan nauki Śniadecki zrobił to wszystko, co mogło być najpożyteczniejszym u nas dla chcących zgłębiać naukę filozofii. Ale najgorliwszymi zwolennikami i obrońcami Śniadeckiego, byli dwaj uczniowie Uniwersytetu Wileńskiego za jego rektorstwa: pułkownik Józef Paszkowski ${ }^{28}$ i profesor Dominik Szulc ${ }^{29}$.

treść dwóch akapitów, które dosłownie brzmią: „Empiryzm Śniadeckiego, który długi czas panował na umysłami Polaków, pożyczony był od teorii Lokka, na której też i wielki mąż się zatrzymał. Schemat Kondyllaka zastraszał go, a dlaczego? Ponieważ czuł, że ze zmysłowej metafizyki Kondyllaka do cynizmu St. Lamberta i materyalizmu doktora Broussais bardzo była mała do przebycia przestrzeń: jakimże więc sposobem zatrzymawszy się na empiryzmie Lokka, od jednego razu przeszliśmy do bezwzględnego idealizmu Niemców! Przejście jest za gwałtowne; lecz nastąpiłoż ono wszędzie? Zrządziłoż ono zmianę w myśleniu u nas? Nie, mała tylko liczba i to wychowańców z silnem pojęciem Berlińskiego filozofa szkoły, przejęła się jego zasadami, większość się niemi nie pożywi i nie potrafi ich strawić. Później może, gdy umysły lepiej będą przygotowane, wzmocniony rozum mas będzie mógł zgłębić otchłań filozofii Niemieckiej, lecz w tych czasach nie jest ona na swoiem miejscu w Polsce. Z drugiej strony nie powinniśmy dążyć matematycznym śladem Śniadeckiego; zatrzymać się jak on, na teorii Lokka, byłoby krokiem wstecznym w filozofii; posunąć dalej sensualizm byłoby niebezpieczne; a zresztą każdej ideologii zmysłowego systematu, brak pewnego czucia i poezji, której pod naszym cierpkim klimatem wśród prozaicznych czynności koniecznie potrzebujemy. Tak więc sensualizm jako heglizm nie są właściwe do rozwinięcia się w umysłach Polaków. Pozostaje nam trzecia i ostatnia szkoła, to jest eklektyzmu, której zasady zdają nam się najstosowniejsze dla naszych współziomków. Nie narzucamy tu błyskotnego eklektyzmu na kształt pana Cousin lub innego jakiego już znanego eklektyka, ale racjonalizmu opartego na pewnych zasadach, zastosowanego do ducha narodu; któryby łączył w sobie zarazem, głębokość szkoły Niemieckiej, zastosowalność empirycznej Angielskiej, rozkład Szkockiej i jasność Francuskiej z XVIII z wyjątkiem tego wszystkiego co jest w niej wbrew obyczajom i antyreligijnego." (s. 276-277).

${ }^{27}$ Chodzi nie krótki esej O filozofii, ale o obszerną Filozofię umystu ludzkiego.

${ }^{28}$ Józef Paszkowski (1787-1858) - wojskowy, pisarz. Od 1831 członek Towarzystwa Przyjaciół Nauk, a od 1833 właściciel niewielkiej szkoły męskiej.

${ }^{29}$ Dominik Szulc (1797-1860) - historyk, jeden z prekursorów polskiego pozytywizmu. Gimnazjalny nauczyciel języka polskiego, wymowy, logiki. Por. W. Kot, Z dziejów kopernikanizmu w filozofii polskiej XIX wieku: Dominik Szulc (1797-1860), Poznań 1973. 
Mianowicie pierwszy w „Pielgrzymie” wychodzącym w Warszawie roku 1841 pod redakcją pani Ziemięckiej ${ }^{30}$, wystąpił w dwóch artykułach bardzo silnie i wymownie napisanych, gdzie w jednym usilnie popierał jego systemat filozoficzny i jego wielkie zasługi w instrukcji publicznej ${ }^{31}$, a w drugim żywy spór zawiódł z Michałem Grabowskim ${ }^{32} \mathrm{z}$ powodu mniemań jego, co do rozprawy [Jana] Śniadeckiego O klasyczności i romantyczności $i^{33}$. W numerze 1 i 4 „Przeglądu Naukowego" w Warszawie roku 1846 wychodzącego, zasługuje na uwagę rozprawa Dominika Szulca: Rozwój zasad umysłu polskiego w piśmiennictwie $e^{34}$, w której wywodząc odrębność właściwej Polakom filozofii, przebiegł pobieżnie wprawdzie, ale dosyć ciekawie, zarody jej u nas w 16 wieku, wspomniał o niestosowności przyswajania między nami filozofii niemieckiej, a z kolei kilka kart poświęcił szlachetnym i wznioślejszym, jak się na pozór zdaje, radom i pomysłom Jana Śniadeckiego, co do nauki filozofii w kraju polskim. Nie możemy tu pominąć tego, co napisał o Śniadeckim, najgłębszy bez wątpienia ze wszystkich, którzy jego filozofii zarzuty robili i najwłaściw-

${ }^{30}$ Eleonora Ziemięcka (1819-1869) - przedstawicielka polskiego mesjanizmu, przeciwniczka filozofii heglowskiej. Redagowała „Pielgrzyma” (1841-1846). Wydała m.in.: Myśli o wychowaniu kobiet, Warszawa 1843; Zarys filozofii katolickiej w czterech poglądach zawarte. Poświęcone pamięci ks. Ignacego Hołowińskiego, Wrocław 1857; Studia, Wilno 1860. Por. J. R. Błachnio, Poglądy filozoficzne Eleonory Ziemięckiej na tle sporów ideowych połowy XIX wieku, Bydgoszcz 1997.

${ }^{31}$ J. Paszkowski, O Janie Śniadeckim, „Pielgrzym”, t. 3, 1842; tenże, Jeszcze słów kilka o Janie Śniadeckim. Do M. G. (Grabowskiego), „Pielgrzym”, t. 2, 1843.

${ }^{32}$ Michał Grabowski (1804-1863) - powieściopisarz, publicysta, krytyk literacki. Por. E. Przechodzki, Pierwsze zarysy porównawczo-syntetyczne historii literatury rosyjskiej i polskiej: S. B. Linde, A. Mickiewicz, M. Grabowski, Lublin 1990; M. Grabowski, Wybór pism krytycznych, wybrał, oprac. i wstępem opatrzył A. Waśko, Kraków 2005.

${ }^{33}$ Chodzi o polemikę Śniadeckiego napisaną w odpowiedzi na rozprawę poety, tłumacza, krytyka i historyka literatury, Kazimierza Brodzińskiego (1791-1835) pt. O klasyczności i romantyczności tudzież o duchu poezji polskiej („Pamiętnik Warszawski”, t. 10, 1818, s. 356-381). Polemika ta ukazała się rok później w „Dzienniku Wileńskim”, t. 1, 1819, s. 2-27 (właściwy tytuł: O pismach klasycznych $i$ romantycznych). Poglądy Śniadeckiego stały się przedmiotem późniejszej krytyki, między innymi Maurycego Mochnackiego (Niektóre uwagi nad poezją romantyczna z powodu rozprawy Jana Śniadeckiego „O pismach klasycznych i romantycznych”, „Dziennik Warszawski”, t. 2, 1825, nr 5, 7; O literaturze polskiej w wieku XIX, oprac. H. Żywczyński, Kraków 1923; Powstanie narodu polskiego w roku 1830 i 1831, opracował i przedmową poprzedził S. Kieniewicz, Warszawa 1984).

${ }^{34}$ Rozprawa ta wydana została dwukrotnie, po raz pierwszy w postaci artykułów w „Przeglądzie Naukowym” (t. 3 z 1845 i t. 1 z 1846 roku), a następnie w postaci broszury (W. Wąsik, Historia filozofii polskiej, t. 2, Warszawa 1866, s. 149). 
szy w swoim czasie znawca tej nauki w naszym kraju, Michał Wiszniewski ${ }^{35}$, w swojej szacownej i zajmującej książce: Bakona metoda tłomaczenia natury (s. 128, w przypisie). Że zaś to jest nie zwykły w obyczajach wielu teraźniejszych u nas krytyków, pełnych zarozumienia, chorobliwej jakiej drażliwości, i żądzy pognębienia wszystkich, co byli niegdyś i będą zawsze zaszczytem naszej literatury, przykład szlachetności w sądzeniu o ludziach: nie wahamy się przytoczyć całkowicie to zdanie uczonego męża, które może dziś służyć za wzór naszym niektórym lekkomyślnym recenzentom, i naukę jak należy szanować prace i zasługi znamienitości naszych naukowych, wtenczas nawet kiedy mamy im cokolwiek do zarzucenia, lub nie zgadzamy się z ich zdaniem! „Nawet w błędach znakomitych ludzi (są Wiszniewskiego wyrazy), jakieś pokrewieństwo w oczy uderza. Podobnie tak B a ko n, u nas Ja n Śn i a decki, otwarcie, bez żadnej ogródki, nie oglądając się znać na wnioski stąd wypadające, twierdzi w piśmie przeciw filozofii Kanta, że nie mas z w człowieku najogólniejszej nawet myśli, która by nie wzięła swego początku od zmysłów; choć zaraz na następnej karcie i po innych o filozofii pismach, i w rozumie pewne wrodzone $\mathrm{zdolności}$ postrzega, i ciągle około tej prawdy krążąc przyznać się do nich nie chce. Nie mówię to w chęci uwłaczania pięćdziesięcioletnim zasługom tego męża, który już w grobie spoczywa; zasługom, które nigdzie prędzej nie idą w zapomnienie, jak u nas. Jego sława uczona nie opiera się na tym, co o filozofii napisał, bo przypadkiem tylko sił swoich w tym zawodzie spróbował. Lękając się, aby filozofia Kanta nie zmąciła pojęcia naszej młodzieży i nie odwróciła jej od nauk fizycznych i matematycznych, które u nas zaszczepił; powstał z właściwą sobie i prawdziwie obywatelską żarliwością przeciwko Kantowi. Płonna to jednakże była obawa, bo czasy scholastyki dwa razy nie wracają, bo wówczas gdy to pisał, nawet w Niemczech, filozofia Kanta już dwakroć się przeobraziła, a u nas ani złej, ani dobrej filozofii nie było. Wszelako tę obronę czystego rozsądku i jasnego rzeczy widzenia, pędzlem Rubensa kreśloną, i ci nawet z rozkoszą czytają, którzy zdania jego dzielić nie mogą; bo rzadko kto $\mathrm{u}$ nas $\mathrm{w}$ tak mocnych i dobitnych wyrazach tłumaczył się, a nikt tak dzielnie, że nie powiem zuchwale językiem polskim nie władał; bo wreszcie on pierwszy dzisiejszy systemat wyobrażeń, nie kalecząc języka przepolszczyć

\footnotetext{
${ }^{35}$ Michał Wiszniewski (1794-1865) - filozof, psycholog i historyk literatury. Profesor Uniwersytetu Jagiellońskiego (1831). W 1848 r. wyemigrował do Włoch. Opublikował m.in.: Bacona metoda tłumaczenia natury (1834); Charaktery rozumów ludzkich (1837); O rozumie ludzkim (1848); Historia literatury polskiej (t. 1-10, 1840-1857). Por. J. Bańka, Poglady filozoficzno-społeczne Michała Wiszniewskiego, Warszawa 1967.
} 
zdołał i język nasz powolniejszym narzędziem myśli uczynił. Lecz gdy tego męża już śmierć z pośrodka żyjących wydarła, gdy nam ani garstki kwiatów na jego świeżym grobowcu rzucić nie zdarzyło się, przystojniej i milej mówić o zasługach jego i geniuszu, niż o pomyłkach"36. Musimy tu jednak dodać, że jeśli Śniadecki, przyswajając naukę filozofów angielskich, nie chciał ostatecznie przyznać rozumowi wrodzonych sił niezawisłych od zmysłów, i przez to razem $z$ nimi wpadł w błąd; na to jednakże zgodzić się nie możemy, że obawa jego o zamęcenie głów młodzi polskiej mistycyzmem Kanta była płonną. W owym czasie bowiem, to jest na lat kilkanaście przed tym, co tu napisał zacny Wiszniewski, już wdarła się ona mianowicie do części dawnej Polski pod panowaniem niemieckim zostających, lub z niego oswobodzonych ${ }^{37}$. Od roku 1815 systemat Kanta i w ogólności abstrakcje szkoły filozoficznej niemieckiej gorliwych znalazły zwolenników w Warszawie, Krakowie i Lwowie. Nie próżno zatem Śniadecki był troskliwym o młodzież uczącą się, zwłaszcza, że i w Uniwersytecie Wileńskim nowa się zjawiła katedra filozofii, której by nie życzył duchem Kanta lub Hegla ożywiać!

Najpóźniejszy sąd o Janie Śniadeckim, jako pisarzu filozoficznym, jest pani Eleonory Ziemięckiej. Równie piękną duszą, jak wielkimi zdolnościami obdarzona, znakomita autorka tylu ważnych pism treści religijno-filozoficznej i moralnej, objawiła to swoje zdanie w Studiach, które wyszły z druku w Wilnie roku 1860, w artykule: Rys piśmiennictwa naszego od roku 1830. W tym krótkim, lecz zasłużonym o nim wspomnieniu wiele jest prawdy w ocenieniu umysłowości jego. Śmiemy jednak powiedzieć, że braknie w tym obrazie kilku niezbędnych rysów, które by mogły dokładniej uwydatnić miarę nauki, talentu i zasług Śniadeckiego. Idzie tu najbardziej o wyjaśnienie powodów, dla których on był tak stałym przeciwnikiem filozofii niemieckiej, czy pożytecznie zrobił wprowadzając do nas nowy element filozoficzny ze szkoły szkockiej, i stawiając go naprzeciw transcendentalności Kanta, a na koniec jak umiał pogodzić religię objawioną z prawdziwą filozofią? Ale może sam czytelnik dopełni teraz owych rysów, których braknie, zważając na stanowisko filozoficzne Śniadeckiego, jakeśmy je dopiero określili wyżej w tym samym rozdziale. Jak Gołuchowski ${ }^{38}$ (w swoich Dumaniach) oderwaną metafizykę

\footnotetext{
${ }^{36}$ M. Wiszniewski, Bacona metoda tłumaczenia natury, Kraków 1834, s. 128-129.

${ }^{37}$ Chodzi głównie o Warszawę i tereny pozostające pod zaborem pruskim.

${ }^{38}$ Józef Wojciech Gołuchowski (1797-1858) - filozof pozostający pod silnym wpływem Schellinga, jeden z prekursorów polskiego romantyzmu, profesor Uniwersytetu Wileńskiego (1821-1824). Autor m.in.: Die Philosophie in ihrem Verhältnisse zum Leben ganzer Völker und einzelner Menschen, Erlangen 1822; Dumania nad najwyższymi zagadnieniami człowieka, Wil-
} 
myślicieli niemieckich, starał się podług zdania pani Ziemięckiej, „zdrowym polskim rozsądkiem" ${ }^{39}$ osadzić na gruncie pojęć swojego narodu; tak również Śniadecki filozofię szkoły szkockiej, chociaż już samą przez się praktyczną, uczynił jeszcze przystępniejszą za pomocą przedziwnej jasności i logiczności swojego wykładu. Oba uniknęli potrzeby tworzenia monstrualnych wyrazów Trentowskiego ${ }^{40}$, i oba usiłowali popularnym wykładem i zrozumiałym językiem wprowadzić w życie tę naukę, nie zaś zostawiać ją przystępną tylko dla małej liczby głów uprzywilejowanych!

\section{Opracował Tomasz Kupś}

no 1861; O wpływie matematyki na wykształcenie człowieka, tłum. M. Mochnacki, „Dziennik Warszawski”, t. 2, 1825, s. 3-36. Dopiero w roku 1823 wygłosił na Uniwersytecie Wileńskim wykład pt. O zadaniu filozofii, obejmując katedrę filozofii, po przeciągających się trudnościach, mimo, że już dwa lata wcześniej wygrał konkurs przedstawiając pracę pt. Zasady logiki, metafizyki i filozofii moralnej (T. Kozanecki, Rozprawa konkursowa (1821) Józefa Gołuchowskiego, „Archiwum Historii Filozofii i Myśli Społecznej”, t. 8, 1962, s. 261-311). Por. S. Harassek, Józef Gołuchowski: zarys życia i filozofji, Kraków-Warszawa 1924; J. Gołuchowski, Filozofia i życie, tłum. P. Chmielowski, red. H. Struve, Warszawa 1903.

${ }^{39}$ Wymienione wyżej wydanie Dumań z roku 1861, poprzedzone jest Wspomnieniem o Józefie Gotuchowskim pióra Eleonory Ziemięckiej.

${ }^{40}$ Bronisław Ferdynand Trentowski (1808-1869) - filozof, pedagog, wolnomularz. Jeden z twórców polskiego mesjanizmu. Znany z wyszukanej terminologii. Opublikował m.in.: Grundlage der universellen Philosophie, Karlsruhe 1837; Chowanna, czyli system pedagogiki narodowej jako umiejętności wychowania, nauki i oświaty, słowem wykształcenia naszej młodzieży, t. 1-2, Poznań 1842; Myślini, czyli całokształt loiki narodowej, t. 1-2, Poznań 1844. Por. W. H. F. Horodyski, Bronisław Trentowski (1808-1869), Kraków 1913.

Projekt został sfinansowany ze środków Narodowego Centrum Nauki przyznanych na podstawie decyzji numer DEC-2012/07/B/HS1/01664 